\title{
The effects of rebranding on customer-based brand equity
}

DOI:

10.1504/ijbg.2019.10009406

\section{Document Version}

Accepted author manuscript

Link to publication record in Manchester Research Explorer

\section{Citation for published version (APA):}

Blazquez Cano, M., Mattich, K., Henninger, C., \& Helberger, E. (2019). The effects of rebranding on customerbased brand equity. International Journal of Business and Globalisation, 22(1, 2019).

https://doi.org/10.1504/ijbg.2019.10009406

\section{Published in:}

International Journal of Business and Globalisation

\section{Citing this paper}

Please note that where the full-text provided on Manchester Research Explorer is the Author Accepted Manuscript or Proof version this may differ from the final Published version. If citing, it is advised that you check and use the publisher's definitive version.

\section{General rights}

Copyright and moral rights for the publications made accessible in the Research Explorer are retained by the authors and/or other copyright owners and it is a condition of accessing publications that users recognise and abide by the legal requirements associated with these rights.

\section{Takedown policy}

If you believe that this document breaches copyright please refer to the University of Manchester's Takedown Procedures [http://man.ac.uk/04Y6Bo] or contact uml.scholarlycommunications@manchester.ac.uk providing relevant details, so we can investigate your claim.

\section{OPEN ACCESS}


Cited as: Blazquez Cano, M., Mattich, K., Henninger, G.E., \& Helberg, E. (2019) The effects of rebranding on customer-based brand equity, International Journal of Business $E^{2}$ Globalisation, in press

\title{
The effects of rebranding on customer-based brand equity
}

\begin{abstract}
The luxury fashion market is predicted to continue to grow rapidly, as millennials are becoming the new luxury consumers. Differentiation from competitors, attracting new consumers, and continuously maintaining brand equity is more challenging than ever, especially for global brands. The purpose of this study is to explore the drivers and process of rebranding and its influence on brand awareness and customer-based brand equity within the luxury fashion market. This study adopts a multi-method qualitative approach, employing semi-structured interviews with practitioners, consumer based focus groups, and semiotics - in order to measure the impact of rebranding processes on customer-based brand equity. The findings outline the most frequent drivers and the crucial steps of a rebranding process for the luxury market. Radical and moderate changes can be made to the brand image and further support customer-based brand equity, yet it is vital to remain true to the original heritage and brand's DNA.
\end{abstract}

Keywords: customer-based brand equity, re-branding, brand knowledge, brand awareness, brand image, brand associations, luxury fashion.

\section{Introduction}

Authors (Muzellec and Lambkin, 2003; Merrilees and Miller, 2008) highlight that the efficacy of rebranding lacks academic support, validation of existing frameworks, and development of specific theory, which is addressed in this article by further focusing on luxury branding, which differs from branding other consumer goods (Kapferer and Bastien, 2012). This article contributes to knowledge by providing a holistic and conclusive picture of the drivers and the process of rebranding, as well as the effects of rebranding these two aspects have on luxury fashion brands and customer-based brand 
equity (CBBE).

As a key economic driving force the luxury market has shown significant growth from 90million luxury consumers in 1995 to over 400million by 2020 (D'Arpizio, 2014). Contributing factor for this increase are more affordable luxury product lines targeted at younger consumers (Roberts, 2012). These younger consumers are often described as 'millennials' (born between 1980 to mid-1990s), who are technology-savvy, selfconfident, and demonstrate individuality (Valentine and Powers, 2013).

Past decades have seen traditional luxury fashion houses either revitalising their brands or completely rebranding themselves making it challenging to maintain their core heritage identity (Kapferer and Bastien, 2012). Internal changes influence the brand's vision, thus, have to be managed carefully and strategically (Amed, 2013). While these changes are easier to control, external influences need to be constantly monitored and dealt with in a timely fashion. Consumers, especially millennials, seek new and more holistic luxury experiences, rather than simply products that embody good quality and design (Atwal and Williams, 2009). Consequently, differentiating the brand from its competitors, attracting new consumers, and maintaining brand equity is more challenging than ever, especially since the fashion industry is one of the most prolific sectors in terms of internationalization strategies with fashion retailers expanding continuously to foreign markets (Moore et al., 2010). Rebranding allows luxury fashion brands to prevent and overcome this challenge, by rejuvenating or repositioning themselves in the market (Muzellec and Lambkin, 2006). This study explores the drivers and process of rebranding and its influence on brand awareness and CBBE.

\section{Literature review}

\subsection{Customer-based brand equity (CBBE)}

The branding process is concerned with the creation and preservation of tangible and intangible brand values that are relevant to potential customers and distinguishes the brand from its competitors (van Riel, 2001). Market positioning through differentiation enables strategic competitive advantage, which allows brands to charge premium prices for products/services, sustain economic downturns, increase market share (inter)nationally, and outperform competitors (Nam et al., 2011; John, 2016). 
Brand equity is conceptualised in a consumer's mind (Elliot and Percy, 2007), which makes the consideration of customer-based concepts vital for evaluating brand equity. CBBE is defined as "the differential effect of brand knowledge on consumer response to the marketing of the brand" (Keller, 1993: 2) and embraces two aspects: brand awareness, which is the ability to recall knowledge after brand exposure and brand image, which reflects the favourability, strength, and uniqueness of brand associations' held by consumers, which comprehensively carries and identifies the consumers' overall brand meaning (Choi, 2014; Samsita and Suki 2015; John, 2016).

Although authors (e.g. Pappu et al., 2005; Keller 2009) have attempted to measure brand equity by focusing on how value is generated, these frameworks have been criticised. Keller (2009) centres on brand awareness (salience) and how it successively adds value in the form of brand performance, brand imagery, brand judgments, and brand feelings, to establish brand loyalty (resonance). Yet, these approaches have been criticised as measuring brand equity is challenging, in that a consumer's brand perception cannot necessarily be quantified on a matrix (Low and Lamb, 2000).

\subsection{Luxury brand equity}

Keller (2009a) created a framework that aims to measure luxury CBBE. He highlights that brand associations are transferred from the brand to the consumer, thereby symbolically improving their self-image (Kapferer, 2008). Within a volatile market (luxury fashion), consumers continuously gain new brand associations (Keller, 2016), thus, it is important for luxury brands to focus on only a few unique brand associations to create a streamlined brand image. Brand associations include:

(1) User profile - demographic reflection of the ideal consumer. Malär et al. (2011) showed that the more the consumer's actual and ideal self overlap, the stronger the emotional brand attachment.

(2) Purchase and usage situation - describes the physical locations where/when the brand is purchased and consumed.

(3) Brand personality, values, history, heritage and experience associations formed by the brand's history and the consumer's relation to it.

Keller (2009a) further identified six brand-building feelings that echo the consumer's emotional response, which are triggered by communication strategies. While warmth, 
fun, and excitement are experiential and immediate, security, social approval, and selfrespect are more subjective, but longer lasting. Atwall and Williams (2009) highlight the importance of including experience in today's luxury brand communication, which can accelerate brand feelings in a consumer's mind.

\subsection{Brand identity / image}

Brand identity refers to what a product/service of the organisation stand for. It is concerned with the overall presentation and communication of the brand to the market and can be interpreted as the brand's positioning (Kapferer, 2008; Urde, 2013). Kapferer (2008) developed a model that allows the comprehensive management of a brand's identity, which is comprised of six interrelated facets: personality, culture, selfimage (which all relate to the brand), physique, relationship, and reflection (which form the outward appearance of the brand). The physique (tangible assets) and personality resemble the sender (luxury brand), whilst the self-image and reflection are shaped by the recipient's perception and shape the brand's image. Thus, the brand image is the reflection of a brand's identity in the consumer's mind and (ideally) enhances CBBE (Biel, 1992; Kotler, 2008). The brand image is built through brand associations, which consumers receive as part of direct and indirect marketing communications. It is vital to carefully maintain a brand identity/image as having a misalignment one can lead to negative brand connotations. 


\section{5 Rebranding and brand equity}

Although not a new phenomenon the literature surrounding aspects of rebranding is scarce and thus far, no common definition has emerged (Goi and Goi, 2011; Miller et al., 2014; Yakimova et al., 2016). Muzellec et al. (2003: 32) define rebranding as "the practice of building a new name representative of a differentiated position in the mind frame of stakeholders and a distinctive identity from competitors". Rebranding is concerned with identifying new sources of brand equity and therefore increasing brand awareness and image (Keller, 2013). Market-leading brands have kept their position by creatively communicating key-elements, which successfully generate a certain 'advertising equity' (Keller, 2013). However, brands also adapt to external market conditions or internal strategic changes by rebranding themselves to restore, keep, or enhance their brand equity (Merrilees and Miller, 2008).

Key drivers for rebranding are mergers (33.1\%), followed by spin-offs (19.9\%), and an out-dated brand image (17.5\%) (Muzellec et al., 2003). The latter is caused by brand crisis (poor publicity or quality) and/or 'brand gremlins', which are employees or entities that are not coherent with the brand's strategy (Farquhar, 2003). The rebranding process is divided into a continuum of 'evolutionary' and 'revolutionary' changes, which can range from minor changes in aesthetics to reinforce a brand, intermediate changes to reposition a brand by applying marketing tactics to create a new image, or complete rebranding (Daly and Moloney, 2004). Although rebranding occurs at the product level, it can impact the entire corporation (Muzellec and Lambkin, 2006; Gotsi and Andriopoulos, 2007).

Three rebranding 'strategies can be identified: re-branding, re-positioning, and relaunch.

\section{Re-branding}

Keller (1999) states that a brand can be revitalized through brand meaning and product differentiation, driven by brand image and awareness. In order to reinforce a functional brand, product innovation, manufacturing, product design, and merchandising need to be improved to enhance product-related performance associations with the potential consumers. Whilst changing the functional product can enhance the brand image and create CBBE, the overall brand meaning needs to stay consistent. Contrarily, symbolic 
brands should highlight "relevance in user and usage imagery" (Keller, 1999: 109) to enhance non-product related imagery associations. This plays a vital role in reinforcing traditional luxury fashion brands (Keller, 2009a). Keller (1999) stresses not to switch between product-related and non-product related brand performance associations to maintain and build a cohesive brand image. In linking this to luxury fashion brand, they should always stress quality, design and history but not switch to functional more comparable brand performances.

Contrary to Keller's (1999) opportunistic approach Aaker (1996) suggests focusing on the brand's heritage, which allows a brand to rejuvenated by exploiting existing values. This process is often referred to as 'retro branding': "the revival or relaunch of a product or service brand from a prior historical period, which is usually but not always updated to contemporary standards of performance, functioning, or taste" (Brown et al., 2003: 20). This definition coincides with Aaker's (1996a) viewpoint that brand rejuvenation lives on exploitation of the brand's heritage and its liked associations.

Challenges associated with the rebranding process are (Gotsi and Andriopoulos, 2007): 1) disconnecting from the brand's core values can alienate customers, as they may not be able to relate and identify with the new brand identity; 2) focusing too strongly on the visual transformation, rather than the overall rebranding of the brand can lead to mistrust and confusion among consumers; 3) neglecting the internal transformation can be fatal for a brand. If internal stakeholders are unable to identify with the new brand identity, their dissatisfaction will be transmitted to customers (Gotsi and Andriopoulos, 2007); 4) all changes made in the branding strategy must be communicated in a unified voice. Internal stakeholders play a key part in the process, thus it is important that they identify with and understand the new brand identity.

\section{Re-positioning}

Muzellec et al. (2003) suggest a 'rebranding mix', encompassing four stages, which can each be adjusted to the relevant type of rebranding. Stage 1 looks at repositioning, whereby the new target customer is determined, whilst keeping the brand's core values (Merrilees and Miller, 2008). Stage 2 is concerned with the adaptation of the visual identity, which links to Stage 3 - the overall redesign of the brand. Stage 4 sees the relaunch of the brand. Changing the visual identity has the most prominent effects on the 
brand's environment and sends a strong message to its customers, thus, it needs to be implemented cautiously (Melewar et al., 2006; Keller, 2013).

\section{Re-launch}

Kaikati and Kaikati (2003) identified four strategies of re-launching a brand's new visual identity: First, 'phase-in/phase-out' strategy links the rebranded brand with the existing brand. The re-launch hence, acts as a transition phase before the old brand is successively eliminated. The customer is slowly introduced to the new brand. Second, the 'sudden eradication strategy' of launching the new brand instantaneously without alerting or pre-warning the customer. Third, the 'translucent warning strategy', which promotes the rebranding strategy prior to and after changes have been made, which raises awareness before and after the event. High communication efforts are needed. Last, the 'counter-takeover strategy', which is most suitable for mergers.

\section{Methodology}

This article utilises an interpretivist, exploratory research design to explore the process of rebranding of two recognized fashion brands and assess its influence on CBBE. This qualitative research incorporates various methodological tools: semi-structured interviews, focus groups, and semiotic analysis. (For reasons of anonymity, the brands are not identified in this article and will be referred to as Brand 1 and Brand 2)

In order to gain an insight into the re-branding processes semi-structured interviews were conducted with industry experts. The experts were selected purposively and comprised of one marketing director (MD), one commercial director (CD), and two creative directors (CR1 and CR2) with extensive branding experience in the luxury fashion segment. Furthermore, as crucial element of a fashion rebranding, a luxury fashion designer (FD) was interviewed. In order to understand the perception of opinion leaders and formers (Smith and Taylor, 2004), a fashion editor (FE) of an established international fashion and lifestyle magazine and a sales/CRM director of an American luxury fashion department store were interviewed. Last, interviews with two academic luxury fashion-branding researchers (FR1 and FR2) enabled a supportive theoretical viewpoint to be attained. Focus groups with consumers allowed studying the impact of rebranding on CBBE. The focus group sample was self-selected to assure luxury consumers and luxury fashion aspiring consumers were interviewed based on their luxury purchases per year and brand awareness of the two selected luxury brands. To 
analyse a continuum from traditional-luxury consumer to emerging consumers, as well as old and new target audiences of brands that have undergone rebranding, the participants selected were of a diverse age and had differing luxury fashion purchase behaviour. A total of 2 focus groups with 6 participants each were conducted. Data analysis followed Easterby-Smith et al.'s (2012) seven-step process of familiarisation, reflection, conceptualisation, cataloguing concepts, re-coding, linking, and reevaluation. Due to multiple researchers coding the individual data sets, this method allowed for patterns and themes to emerge organically. Discrepancies were carefully looked at and iteratively coded. The final results were presented to participants for validation.

This study is focused on traditional luxury fashion houses carrying strong brand heritage. Moreover, both Brands 1 and 2 have undergone a re-branding process in 2012. Brand 1 rebranded an obsolete brand moderately, while Brand 2's rebranding process was more radical. The choice was further supported by high media attention accompanying both brands during the rebranding process, and the strong industry resonance after.

\section{Findings}

\subsection{Process of luxury fashion rebranding}

The most frequently mentioned drivers within this research for a luxury fashion rebranding were financial underperformance and an out-dated brand image. Reasons therefore are often "when a company has lost its core story and no longer has clear direction" (CR2). Rebranding allows brands to stay relevant and competitive, and expand their target audience.

Data suggest that both Brands 1 and 2 aimed to reposition their image. Brand 1 needed to rebrand to regain awareness and overcome its underperformance, whereas Brand 2 needed to regain its status of a French luxury fashion house and reinforce its former brand image.

Both brands' intended to target a younger audience showing that rebranding often acts as an introduction to a new target market and hence a new era for a brand. The new target audience needs to be identified and determined, according to the aim of the respective rebranding strategy. The scope of rebranding luxury fashion houses depends 
on each brand's market position and performance at the time, and the designer's brand vision. Evolutionary changes maintain, whilst at the same time refresh an existing luxury fashion brand identity. Although, this approach is less risky and recommended for more well-performing brands, it creates less impact and awareness raising among consumers. A majority of interviewees suggest $360^{\circ}$ revolutionary rebranding delivers a consistent new brand image and generates higher awareness. Depending on how essential the rebrand is, a more or less radical approach is suggested, which than generates higher awareness.

Data suggest that a radical change helps brands to change their brand identity/image if they have previously been either forgotten or wrongly positioned. Yet, a risk that is associated with this approach is the alienation of existing customers. Creative director 2 highlights, "with each brand and each vision for rebranding, [the scope] is different from case to case. The vision of the rebranding has to be true to the DNA of the brand". Thus, it is vital that these luxury fashion brands keep true to their heritage and core values.

\section{Initial steps}

The interviewees unanimously agreed that "you can change everything about your brand, but if you don't change the product a rebranding doesn't make any sense" (FD). It was highlighted that before product changes are implemented, a clear vision needs to be established, which reflects the 'new' target audience.

According to our data vital steps for rebranding a luxury fashion house can be summarised as:

(1) Current and future customer needs must be identified.

(2) Designer's brand vision assures a cohesive brand identity is delivered and builds the brand around the product.

(3) Based on the newly defined target audience and brand vision, the product, needs to be changed. However, it is important that new collections remain relevant to the brand's heritage and core.

\section{Product}

The product is not only the most important element of a rebranding process, but also forms the "ultimate embodiment of the brand identity" (FR1) and is a central source of inspiration for all additional brand building elements. The Commercial Director highlights that within the rebranding process it is vital to refer back to the brand's core 
values and heritage thereby making sure to strike a balance between the original core elements that made the product famous and product innovation. This will ensure to cater for both existing and new customers. To explain, new collections and rebranded products must have at least the same standard of quality as the 'original' product, if not exceed it (SD, FR1). Thus, if a new designer is invited to take on and 'rebrand' a luxury fashion line, they (designers) need to have profound knowledge of the brand's heritage and invest time in identifying the brand's new direction (FR1). Depending on the designer's brand vision and changed product, communication and distribution channels need to be adjusted (CD, GMD). Our data indicated that both brands managed to implement new permanent product lines, which are highly recognisable and thus enable brand recognition.

\section{Price}

Depending on the brand's new direction and target audience, changing the pricing strategy is crucial, but risky. Brand 1 decreased their prices and introduced lower priced buy-in products, which helped to attract a younger audience, thereby strategically transforming them into loyal customers (FR1). Contrarily, Brand 2 increased their prices, which reinforced exclusivity of this luxury fashion brand (CD, FR1, FR2). Corresponding product quality is key to justify the increased price (CR2). Data indicate that luxury fashion consumers have a high price elasticity, as long as the product can justify a price change, increasing prices is not as risky as lowering them, as the latter can imply losing prestige (CD). Consequently, according to new target audience, product quality, range and prices need to be adapted.

\section{Visual identity}

The following section clarifies the need and scope of changing a luxury fashion brand's visual identity (brand name, logo, POS). Key drivers for changing a luxury fashion brand's visual identity are: 1) they become obsolete, 2) they no longer match the brand's content and/or environment anymore, or 3) they have a changed target audience. A new visual identity expresses the brand's new vision and values in 'tangible forms' (GMD). Modifications to the visual identity can be moderate or radical, but should be implemented every 7-10 years to keep the brand up-to-date (CD). 


\section{Brand name}

Data indicate that changing a luxury fashion brand's name is a highly sensitive and risky process and not recommended by participants. The main reason is that traditional luxury fashion brands are eponymously named after their founders. By changing the brand name, the link between the name and the heritage, values and thus, brand recognition, awareness, and authenticity are eliminated (CD). Yet, depending on how established a brand is, name adaptations are possible. This only applies to brands, which were once personalities, thus the first name may be eliminated, such as 'Coco Chanel' to 'Chanel' or 'Christian Dior' to 'Dior' (FE, FD). Yet, name adaptations should be accompanied by a strong rational.

\section{Logo}

Interviewees recommend updating logos only to keep them modern. Similarly to the luxury fashion brands' names, logos should not be replaced or changed too drastically, as it is part of their heritage. Changing a logo too dramatically can negatively affect brand recognition, awareness, and the brand's identity, thereby alienating customers (CD). Logo changes are costly and should only be changed if there is a strong rational. To explain, if the purpose of rebranding is a refreshed look adding or eliminating additions to the brand's logo are possible (GMD). Slight changes of the logo's font or layout can help to signalize a change within the brand to its customers. During its rebranding, Brand 1 changed the brand's font and added 'Paris' to the brand's logo (Semiotics). In the case of Brand 2, even though the brand name was shortened, its multiple letter logo remained the same on products (Semiotics), which can cause customer confusion (CD).

\section{Point of sale (POS)}

The store design, as part of the visual identity, should be kept up-to-date to convey the brand's values (CR2) and environment (CD). A significant change in target audience calls for a new store environment, embodying the brand's new direction and brand world (FE, FD, FR1). Changes in positing demand a "radical generational change" (CR1), which needs to be executed in its POS.

Flagship stores should lead the change and act as blueprints for further store renovations. CR1 highlights, the POS "is the all encompassing culmination of the brand 
representation. [...] and tends to have more staying power than a season's of ads. It's integral to the branding process and requires reinvention when the brand is making significant strides to reimage itself in the market. It's where the end consumer will have his/her fullest impression. Usually it's one of the latter things to be done".

Brand 2 completely reinvented its physical store environments simultaneously across all stores (semiotics), which confirms Moore et al. (2010), who see POS as a market entry or re-entry strategy. Brand 1's flagship store was also renovated. Before opening further POS, new shop-in-shops were opened in department stores to reintroduce the brand to new customers.

\section{Extend of change}

Data remained inconclusive in terms of how much a luxury fashion brand's identity should be changed. FE claims that changing a traditional Parisian luxury fashion brand's identity means cannibalisation, yet, MD and FR1 insist that it is possible. Although no conclusions can be drawn, it can be said that as long as the rebranding has a strong rationale and logical connection to the brand's heritage, the scope of change can vary in each case.

Interviewees were asked whether it is possible to use rebranding as a tool to change luxury fashion brands into luxury lifestyle brands, as was the case for Brand 1 (Semiotics). Interviewees stated that as long as the lifestyle is manifested (GMD) and the brand has a strong equity (FR1) it is possible to expand the brand.

\section{Marketing communications and rebranding}

\section{- Advertising}

Rebranding provides an opportunity to communicate changes to the target audience, by adapting communication strategies (FR2, CD, GMD). Celebrity testimonials (e.g. brand awareness) or heritage references (e.g. brand recognition) are recommended. The new target audience must feel connected to the new brand image in order to build a relationship.

Brand 2 drastically changed its visual language by divorcing from a feminine and sophisticated image and adopting a Rock'n'Roll, grunge image. Whilst this raised awareness, it also reduced brand recognition. Brand 1 also changed its advertising 
strategy from nature-related imagery to abstract and more contemporary campaigns (CR2) but kept references to Brand 1's original preferences for wild patterns and colours.

\section{- Fashion shows}

Fashion shows are essential to rebranding and represent "the [brand's] different vision, it's important for each designer to express their vision for the house or the brand and that includes the show" (FE). Even though several interviewees state that a fashion show is still a B2B communication tool, due to live streaming and websites, fashion shows have a great reach (GMD). A fashion show visualises a point of differentiation (CR2) and enhances its new identity (GMD), yet it must reference the brand's DNA (FR2). The size of a show, the celebrities invited and the awareness created depend on the designer's vision and direction for the brand.

Brand 2's first fashion show received a lot of media attention (Semiotics) because the show and vision were clearly different from Brand 2's former shows. Similarly, Brand 1's fashion shows changed by incorporating a performance art character style (Semiotics) in which artists, film producers, musicians, and celebrities not only support the show by attending, but also actively help create them.

\section{- Celebrity endorsement}

Interviewees insist that celebrity endorsement is vital during the rebranding process. It is crucial to identify celebrities that best match the new brand's vision and identity. A new spokesperson is therefore not just part of the brand's new identity but helps form it initially. FR1 argues celebrities endorsing the brand are a "big trigger for [customers] to understand how the personality of the brand has changed [and] it's easier for them to digest or understand the rebranding". Interviewees highlighted the importance of finding the right and unpredicted celebrity, while using generic spokespersons was dissuaded (CD2).

\section{- Vital marketing communication efforts}

The Focus Group research did not uncover any one tool that is most effective during rebranding (Focus Group 1,2). Depending on the brand and its personality, an integrated approach using several marketing communication tools, aimed at the new target audience needs be implemented to be most effective. The emphasis on the use of 
diverse communication tools varies depending on the budget and target audience, but communications should always convey one coherent new voice (CD, GMD). Print advertising and digital touch points (websites, social media) were argued to be effective communication tools, as they have a wide reach (SD, FR1). Convincing opinion formers of the luxury fashion industry is crucial for securing the rebranding's media coverage. Interviewees also stressed the importance of a unique design voice and great product as a source of the brand's communication strategy.

\section{Success measurement}

Positive cash flow is identified as a clear measure of the success of rebranding a luxury fashion brand. Interviewees agreed that a positive resonance from the industry's opinion formers and customers about the rebranding and hence, a positive new brand image were also thought of as valid measures of success (FG1). Customer counts, press clippings, online tracking, and celebrities endorsing the brand, act as indicators for a successful luxury fashion rebranding (CD1).

In the case of Brand 2, even though the opinion formers' and customers' opinions still differ widely, the financial development clearly demonstrates a rebranding success (Semiotics). Similarly, Brand 1 is financially recovering from its downturn during the time of the former designer's brand leadership (Semiotics). These results highlight the importance of a clear brand vision, as well as its translation into the product in order to target a specific audience. Brand 2's radical approach was very risky, yet helped generating global awareness. For Brand 1, the key success factor was the ability to build a young and unique community through product and communication (Semiotics).

\section{Impact of rebranding on Brand 1 and 2's CBBE}

\section{Brand 1}

\section{Brand feelings/associations}

Brand 1's rebranding caused an evident shift of brand feelings and associations within the focus group's participants. Their associations with Brand 1's former image were colourful, fresh, easy, flowing, heavily nature-related, and "the patterns and colours" (Focus Group). However, the younger participants described it as "pretty boring and humdrum". After the rebranding, the older participants consider the brand as adapted, odd, random, graphic, and no longer happy, playful or "Brand 1" anymore. By contrast, 
the younger participants describe the new image as modern, urban, fresh, playful, loud, and digitalised. An evident discrepancy evolves, stressing the shift of target audience towards a younger and more fashion-embracing consumer.

\section{Brand personality}

Brand 1's personality was affected by the rebranding. Previously the brand embodied a relaxed woman of any age, working independently in the creative industry and heavily in tune with nature and outdoors activities. After the rebranding it was described as a unisex 20-30 year old Asian person, living in worldwide capitals and working in the creative, digital fashion industry. S/he belongs to a certain 'cool' and like-minded group of people by wearing Brand 1 and is heavily engaged with social media. The change of brand personality stresses the obvious shift in target audience to a new age and market. The brand distanced itself from its former target audience who clearly do not recognise the brand anymore: "I feel like I don't know the brand anymore". Brand 1 has thus created a new brand community, by also refocusing on a male audience.

\section{Usage situation}

Whilst the 'original' brand was perceived as a casual summer brand for vacation on the beach, the rebranded Brand 1 has become more of an everyday statement for creative people, demonstrating their affiliation to a group of like-minded people, wearable in big cities worldwide. The designer's intention to make Brand 1 a lifestyle brand becomes only apparent by the created brand community, which its former target group cannot identify with (Focus Group).

\section{Purchase situation}

The participants agreed that before the rebrand, Brand 1 was mostly purchased in department, multi-label, and Brand 1 stores. Due to the brand's distinctiveness after the rebranding, Brand 1 store, specific modern multi-label and the brand's online store have become the first choice of store. This again links to its intention to create a community for which Brand 1 and some specific trendy multi-label stores are touch and meeting point (Focus Groups).

\section{History and experiences}


While the younger participants knew the former Brand 1 only because of its perfume and their parents' experiences with the brand, the older participants still referred to it as the original Parisian house that was famous for playing with colours and patterns. It becomes apparent that the older participants cannot relate to the rebranded Brand 1, while across the younger participants the brand is heavily known for a characteristic print. A participant's statements demonstrates how successful Brand 1 has shift its target audience: "The kids of a friend of mine are like 13 and 15 years old and they knew the sweater [print] when they saw it in the store and they wanted it!"

\section{Brand 1 summary}

The rebrand successfully re-established Brand 1 as a contemporary luxury fashion brand. The brand offers bold products, which due to big logos can boost self-image/ego (James, 2011). Brand 1 was almost dead prior to the rebrand, the choice to change target audience was obvious. Targeting a younger audience, allows a new long-term customer base to be built.

By creating such a distinctive and strong brand identity the brand created a base on which to expand product categories and make Brand 1 a lifestyle brand. However, building such a specific brand community also alienates several potential customers.

\section{Brand 2}

\section{Brand feelings/associations}

Both focus groups described Brand 2 as a feminine, elegant, wearable, and classy brand for grown-up personalities. After the rebranding, the brand association changed evidently towards a more contemporary Rock'n'Roll, young, fashionable, and rebellious image. However, the older participants stressed that Brand 2's elegance and unique identity had faded: "I would never ever again associate this with (Brand 2). At least the way I know it from back in the days. Not at all'. Hence it has become more random, comparable to other brands, and in a way disposable.

\section{Brand personality}

The former brand personality of Brand 2 is described as a female, wealthy, 35-40 year old international socialite, who is cultivated, chic and determined, who travels and lives in global capitals. Brand 2 now is described as unisex, carefree, 20-year-old party kid who works or enjoys the music industry in Hollywood. Thus, a drastic change of brand 
personality is evident, attracting a younger audience and emphasizing the brand's menswear.

\section{Usage situation}

Brand 2's usage situation changed significantly to a younger audience. While people in social representative roles, going to evening galas and social events mainly bought the original brand, Brand 2 is bought for use in everyday life, a lively nightlife, amusement and leisure activities (Semiotics). Thus, older and younger participants agreed that the brand is going through a generational change and responding to the new customers' desires.

\section{Purchase situation}

Across age groups, participants agreed that Brand 2 was mostly bought at Brand 2 stores, where consumers can enjoy a comprehensive shopping experience and respective sales advice, or occasionally at luxurious department stores. Contrary, all participants also agreed that the new Brand 2 could be purchased in diverse stores because of the possibility of mixing the new collections with other brands, while the original Brand 2 brand was bought for complete looks. Hence, even though Brand 2's exclusivity was regained by raising the prices, accessibility in regards of distribution could be facilitated.

\section{History and experiences}

While the younger audience only recalled the original Brand 2's cosmetics and a particular shoe model, the older participants were aware of key themes and elements of Brand 2's original collections. Older participants can no longer relate to Brand 2's new collections and argue that the brand lost its unique identity. Younger participants can only recall Brand 2's salient new print campaigns and celebrity endorsement. Consequently, Brand 2 still needs to implement some memorable key elements into its new identity.

\section{Brand 2 summary}

The rebranding of Brand 2 restarted the brand and thus, had evident impact on its CBBE. While it can be argued that Brand 2 lost major CBBE because the old target audience cannot easily identify with Brand 2's identity, the upcoming generation sees a stylish, contemporary and cool luxury fashion brand, which speaks to men and women

\section{Discussion}


Muzellec et al. (2003) state that mergers and spin-offs are generally the most common reason to rebrand; this is different for the luxury fashion sector where an out-dated image and financial underperformance are the main drivers - which is a key contribution of this article. Additionally, rebranding can be applied to expand the target audience by repositioning the brand to appeal to a new target customer.

The designer's brand vision acts as a brand mission and thus, provides a guideline for the brand's transformation by nurturing brand and visual identity. Based on the brand vision and current and desired target audience, the new target customer is identified. This process is the same as a situational analysis, crucial before any changes are made to the marketing mix (Merrilees and Miller, 2008).

This research concurs with Gotsi and Andriopoulos (2007), who argue that changes that are too drastic can lead to disconnect from the brand's core and dilution of brand recognition. Consequently, the luxury fashion brand's DNA must be referenced when creating a new vision. A complete divorce from a luxury fashion brand's former identity, as in other sectors (Daly and Moloney, 2004) is self-defeating because it prevents exploiting the brand's history and aura (Brown et al., 2003).

For luxury fashion brands, a revolutionary approach that encompasses all brandbuilding elements is more effective compared to evolutionary changes which refresh a brand with slight changes in only a few brand-building aspects (Stuart and Muzellec, 2004). How radically to change depends on the designer's brand vision and therefore, determines how far Kapferer's (2008) brand identity components are altered. Unlike other industries (Daly and Moloney, 2004; Lomax and Mador, 2006), name and logo change are nearly impossible for luxury fashion brands, which is a further key contribution of this article.

Changing the entire promotion strategy according to the brand's new vision and new product creates a brand new visual voice and creates changes in user and usage imagery (Keller, 1999) because changing fashion's functional aspects are hardly possible. Our research demonstrates the importance of considering traditional and non-traditional advertising and other marketing options in order to successfully measure CBBE (Keller, 1993). Communications have profoundly changed in the last years and the importance of concepts such as co-creation and word of mouth is worth to be considered (Keller, 2016). In agreement with the literature, the POS is a crucial part of a luxury fashion brand's visual identity and communicates the rebranding as one of few tangible touch 
points for the customer. Furthermore, it acts as re-entering strategy in the rebranding process.

Similarities between Keller's (1999) path of brand reinforcement and Muzellec et al.'s (2003) repositioning are apparent. However, this investigation showed luxury fashion rebranding are more vision-orientated rather than based on consumer demand. This again links to Kapferer and Bastien's (2012) statement that luxury brands should set a desire customers follow rather than cater to consumer demand. 


\section{Conclusion and implications}

This study explored the process of rebranding luxury fashion brands in order to maintain and/or regain $\mathrm{CBBE}$. The qualitative investigation revealed that rebranding luxury fashion brands is a highly complex process, encompassing several risks and pitfalls and thus needs to be adjusted individually to each case.

It is crucial to create a contemporary and attractive brand identity that consumers want to buyin and identify with. Identifying the right target audience is essential to create a corresponding brand identity. To create a consistent and recognisable new visual voice for the brand all brand-building elements need to be integrated. The focus groups revealed how luxury fashion brand images can be shifted towards a completely new direction by implementing a new clear brand vision into all marketing communication tools.

The investigation further showed that repositioning a luxury fashion brand and changing the target audience requires a more radical approach. This not only causes a prominent change within the brand, but also simultaneously raises awareness. However, a strong rational and references to the brand's DNA must support the choice of radical approach, so that long-term brand recognition can be established.

A more moderate approach was identified to reinforce out-dated or obsolete luxury fashion houses. It is crucial that luxury fashion houses adjust their former brand identities according to the current spirit of the time. Again, this requires adapting all marketing communication tools in strict alignment with the designer's new vision. However, due to the loss of brand awareness of obsolete brands, radical changes should be avoided to successfully reinforce customer-based brand equity.

Depending on each luxury fashion brand's history, current market position and strategic capabilities, a balance between incorporating brand heritage and revolution must be found. Varying with the respective designer's brand vision and newly identified target audience, the exact scope between moderate and radical revolutionary must be identified and implemented.

This study has identified several managerial implications, which support successful rebranding of luxury fashion brands and maintenance or regaining CBBE. First, marketers need to be aware of the fundamental importance of a new brand vision. Hence, the choice of a new designer should be based on the designer's sense of meeting the current spirit of the time and ability to merge their vision with the brand's existing identity. Thereby, a novel and unique brand identity needs to be created so the brand does not become comparable to other 
brands. Also, because of the wide range of luxury fashion brands available today, it is important to target a specific yet substantial and lasting audience. Using the product to enable customers to visually identify themselves with the brand further improves the customer's selfimage and the customer-brand relationship.

Second, depending on the aim of the rebranding strategy, a more moderate or radical approach must be considered. Brand name and logo changes are part of the most radical approach and highly sensitive in regards of affecting brand recognition and thus, highly risky. However, the other end of the rebranding continuum also calls for adaptations in every aspect of the visual identity. Print advertising and digital touch points (website/social media) are identified as the widest reaching communication tools. Furthermore, a consistent branding concept, referencing heritage, builds brand recognition. Thus, any changes need to be carefully considered and benefits and drawbacks measured in accordance to potential gains and losses.

The role of brands and branding are changing in the digital world and CBBE frameworks should consider the impact of the change in consumer' decision journey and path to purchase (Keller, 2016). Targeting and building relationships with customers need to be reevaluated and hence need to be the factors involved in re-branding processes.

This research has aimed to contribute to a better understanding about CBBE. Further challenges in the measure of this construct involves the consideration of new realities within global and connected world (Swaminathan, 2016, Gürhan-Canli et al., 2016).

\section{Limitations}

The focus was on the visual and tangible aspects of the rebranding process. Hence, a company internal investigation and validation by Brands 1 and 2 in form of two extensive case studies leaves room for further investigation. Second, an inevitable limitation was the impossibility of measuring the brand equity of Brands 1 and 2 before the rebranding in an unbiased way. This is because the focus group participants' knowledge of the current branding strategies of Brands 1 and 2 could have influenced their perception of the old versions of the brand. Only a longitudinal study starting prior to rebranding could eliminate this bias. Lastly, the cross sectional nature of the data collection made it difficult to measure long-term impact of a luxury fashion rebranding on CBBE. Since, both houses rebranded recently, a longitudinal 
study would aid further investigation and evaluation of long-term effects of rebranding on CBBE.

\section{References:}

Aaker, D.A. (1996), 'Measuring brand equity across products and markets', California Management Review, 38(3): 102-20.

Aaker, D.A. (1996a), Building strong brands. Free Press: New York.

Amed, I. (2013), Why Creative Directors Matter More Than Ever - BoF - The Business of Fashion. BoF (online), Available: http://www.businessoffashion.com/2013/06/whycreative-directors-matter-more-than-ever.html, Accessed 06/09/2014.

Atwall, G. and Williams, A. (2009), 'Luxury brand marketing - the experience is everything!', Journal of Brand Management, 16(5): 338-346.

Biel, A.L. (1992), 'How brand image drives brand equity', Journal of Advertising Research, 32(6): 6-12.

Brown, S., Kozinets, R. and Sherry, J. (2003), Teaching Old Brands New Tricks: Retro Branding and the Revival of Brand Meaning, Journal of Marketing, 67(3): 19-33.

Choi, T.M. (2014), 'Fashion Branding and Consumer Behaviour', Springer: Heidelberg.

D'Arpizio, C. (2014), Luxury Goods Worldwide Market Study Winter 2014 - Bain and Company - Publications. Bain (online) Available: http://www.bain.com/publications/articles/luxury-goods-worldwide-market-studywinter-2014.aspx, Accessed: 4/09/2014.

Daly, A. and Moloney, D. (2004), 'Managing Corporate Rebranding', Irish Marketing Review, 17(1/2): 30-36.

Easterby-Smith, M., Thorpe, R., and Jackson, P. (2012), Management Research. $4^{\text {th }}$ edition. SAGE: London.

Elliott, R. and Percy, L. (2007), Strategic brand management. $1^{\text {st }}$ edition,Oxford University Press: Oxford

Farquhar, P. (2003), 'Editorial: uncovering brand gremlins and other hidden perils', Journal of Brand Management, 10(6): 388-92.

Goi, C.L. and Goi, M.T. (2011), 'Review on Models and Reasons of Rebranding', International Conference on Social Science and Humanity IPEDR vol.5 IACSIT Press, Singapore.

Gotsi, M. and Andriopoulos, C. (2007), 'Understanding the pitfalls in the corporate rebranding process', Corporate Communications: An International Journal, 12(4): 341-355.

Gürhan-Canil, Z., Hayran, C., and Sarial-Abi, G. (2016), 'Customer-based brand equity in a technologically fast-paced, connected, and constrained environment', 6(1), pp. 17-22

James, W. (2011), 'The appeals of luxury advertising: an application of Taylor's six segment message strategy wheel', The Elon Journal of Undergraduate Research in Communications, 2(2), pp.62-75.

John, D.R. (2016), 'Customer-based strategic brand management: past progress and future challenges', AMS Review, 6(1), pp. 23-32

Kaikati, J. and Kaikati, A. (2003), 'A rose by any other name: rebranding campaigns that work', Journal of Business Strategy, 24(6): 17-23.

Kapferer, J. (2008), The new strategic brand management, $1^{\text {st }}$ edition, Kogan Page: London Kapferer, J. and Bastien, V. (2012), 'The luxury strategy: break the rules of marketing to 
build luxury brands', $2^{\text {nd }}$ edition, Kogan: London

Keller, K. (2016), 'Reflections on customer-based brand equity: perspectives, progress, and priorities', AMS Review, 6(1): 1-16

Keller, K. (2013), Strategic brand management: building, measuring, and managing brand equity, Pearson, Harlow.

Keller, K. (2009), 'Building strong brands in a modern marketing communications environment', Journal of marketing communications, 15(2/3): 139-155.

Keller, K. (2009a), 'Managing the growth tradeoff: Challenges and opportunities in luxury branding', Journal of Brand Management, 16(5): 290-301.

Keller, K. (1999), 'Managing Brands for the Long Run: Brand Reinforcement and Revitalization Strategies', California Management Review, 41(3): 102-124.

Keller, K. (1993), 'Conceptualizing, measuring, and managing customer-based brand equity', Journal of Marketing, 5, pp. 1-22.

Kotler, P. (2008), Principles of marketing, Prentice Hall: Harlow.

Lomax, W. and Mador, M. (2006), 'Corporate re-branding: from normative models to knowledge management', Journal of Brand Management, 14(1), pp.82-95.

Low, G. and Lamb C. (2000), 'The measurement and dimensionality of brand associations', Journal of Product and Brand Management, 9(6): 350-370.

Malär, L., Krohmer, H., Hoyer, W. and Nyffenegger, B. (2011), 'Emotional brand attachment and brand personality: the relative importance of the actual and the ideal self', Journal of Marketing, 75(4): 35-52.

Melewar, T., Bassett, K. and Simoes, C. (2006), 'The role of communication and visual identity in modern organisations', Corporate Communications: An International Journal, 11(2): 138-147.

Merrilees, B. and Miller, D. (2008), 'Principles of corporate rebranding' European Journal of Marketing, 42(5/6): 537-552.

Miller, D., Merrilees, B., and Yakimova, R. (2014), 'Corporate rebranding: an integrative review of major enablers and barriers to rebranding process'. International Journal of Management Reviews, 16: 265-289.

Moore, C., Doherty, A. and Doyle, S. (2010), 'Flagship stores as a market entry method: the perspective of luxury fashion retailing', European Journal of Marketing, 44(2): 13961.

Muzellec, L., Doogan, M. and Lambkin, M. (2003), 'Corporate rebranding - an exploratory Review', Irish Marketing Review, 16(2): 31-40.

Muzellec, L. and Lambkin, M. (2006), 'Corporate rebranding: destroying, transferring or creating brand equity?', European Journal of Marketing, 40(7/8): 803-824.

Nam,J., Ekinci, Y., and Whyatt, G. (2011), 'Brand equity, brand loyalty and consumer satisfaction', Annals of Tourism Research, 38(3): 1009-1030.

Pappu, R., Quester, P. and Cooksey, R. (2005), 'Consumer-based brand equity: improving the measurement - empirical evidence', Journal of Product and Brand Management, 14(3): 143-54.

Roberts, A. (2012), Kenzo Aiming to get Hip Again under New Leadership. [online] Bloomberg. Available at: http://www.bloomberg.com/news/2012-06-28/kenzoaiming-to-get-hip- again-under-new-leadership.html [Accessed 11 Sep. 2014].

Sasmita, J., and Suki, N.M. (2015), 'Young consumers' insight on brand equity', International Journal of Retail \& Distribution, 43(3): 276-292.

Smith, P.R. and Taylor, J. (2004), Marketing communications: an integrated approach, $4^{\text {th }}$ edition Kogan Page, London.

Stuart, H. and Muzellec, L. (2004), 'Corporate makeovers: can a hyena be rebranded?', The Journal of Brand Management, 11(6), pp.472-482. 
Swaminathan, V. (2016). Branding in the digital era: new directions for research on customerbased brand equity. AMS Review, 1-6.

Urde, M. (2013), The corporate brand identity matrix, Journal of Brand Management, 20(9): $742-761$.

Valentine, D.B. and Powers, T.L. (2013) Generation Y values and lifestyle segments, Journal of Consumer Marketing, 30(7), pp. 597-606

van Riel, C.B.M. (2001) Corporate Brand Management, Thexis, 4, pp. 12-16

Yakimova R., Merrilees B., Miller D. (2016) Engaging Internal Stakeholders: Revitalizing Community Organizations Through Rebranding. In: Campbell C., Ma J. (eds) Looking Forward, Looking Back: Drawing on the Past to Shape the Future of Marketing. Developments in Marketing Science: Proceedings of the Academy of Marketing Science. Springer,: Heidelberg 